\author{
Vasko, A.A., Marchenko, A.A., Naumovets, A.G., and Braun, O.M. \\ Institute of Physics of the NAS of Ukraine, \\ 46, Nauki Ave., Kyiv, 03680, Ukraine, \\ +380 44525 1220, +380 44525 1589, artem.vasko@ukr.net
}

\title{
STUDYING THE TRIBOLOGICAL PROPERTIES OF $n$-ALKANES MONOLAYER FILMS ON ATOMICALLY FLAT SURFACE OF GOLD
}

\footnotetext{
Introduction. The establishment of regularities of the microcontact interaction in the friction interface formed by two moving bodies is an important step towards the creation of new classes of materials with predefined physicochemical properties. The relative motion of interacting surfaces inevitably results in wearing contact areas (microcontacts) of these surfaces, i.e. leads to the formation of fragments caused by destruction of more elastic material.

Problem Statement. The destruction of the interface decreases significantly by applying lubricant films to the contact area. In the case of dry friction (no lubricant), the description of the contact area is a practically solved problem (the Hertz and the Johnson-Kendal-Roberts contact theories), while the presence of lubricant complicates significantly this problem, because one shall consider the rheological component of friction and the interaction of interfaces. In addition, the overwhelming majority of tribological studies were carried out using imperfect (rough) surfaces and lubricant films with uncertain component composition, thickness, and structure.

Purpose. To establish the influence of the structure of self-assembling $n$-alkanes monolayers on their tribological properties in the frictional interface.

Materials and Methods. The atomically flat surface of gold and one-component monolayer films of $n$-alkanes $\left(C_{n} H_{2 n+2}\right.$, $n=14,16,48,50,60)$. are used as materials. The scanning tunneling microscopy method is used to establish the structure of self-assembled monolayers on the gold surface as well as to control their destruction before and after the tribological measurements. The kinetic coefficient of friction $\mu_{k o}$ of interfaces have been studied using a magnetic levitation tribometer.

Results. The nonmonotonic dependence of kinetic friction coefficient $\mu_{k o}$ on the length of $n$-alkane molecule has been experimentally established.

Conclusions. The kinetic friction coefficient $\mu_{k o}$ has been established to abnormally decrease for the $n$-alkanes with "magic length" ( $n$ times 16).

Keywords: coefficient of friction, atomically flat surfaces, monolayer films of $n$-alkanes, and friction force.
}

Establishing the patterns of interaction of microcontacts in the frictional interface formed by two moving bodies is an important step towards the creation of new classes of materials with certain physicochemical properties [1,2]. As the interacting surfaces moves one relative another, their contacting areas (microcontacts) inevitably wear out with the formation of debris in the frictional interface [3] as a result of the destruction

(C) VASKO, A.A., MARCHENKO, A.A., NAUMOVETS, A.G., and BRAUN, O.M., 2019 of more elastic material. Numerous experiments have shown that the friction force is not constant and varies depending on the previous interaction of microcontacts (contact aging) [4-6].

The degree of interface destruction is known to reduce significantly if lubricating films are applied to the contact plane. In the case of dry friction (no lubricants), the contact point analysis has been practically completed (the contact interactions theory by Hertz and Johnson-KendallRoberts), whereas the presence of lubricants sig- 
nificantly complicates the problem because of the need to consider the rheological component of friction and the interface interaction [7]. It should be noted that the overwhelming majority of tribological studies have been carried out on imperfect (rough) surfaces using lubricating films with uncertain component composition, thickness, and assembly structure. This has made it impossible to determine the impact of each factor individually. The following studies have been done for the first time on atomically flat surfaces covered with ordered monolayer films with established component composition [8,9] and predictable changes in their tribological properties [7, 9-11].

In order to identify the appearance of defects at the atomic level and to establish non-destructive modes of friction studies under certain loads researchers have used the methods of scanning, frictional, and atomic force microscopy [1214]. However, these methods have not enabled to fully describe the tribological properties of lubricating films on atomically flat surfaces [3, 7]. That is why these studies require the creation of special experimental conditions and instruments for measuring friction [15].

This research proposes a fundamentally new non-destructive method for studying the lubricant/surface friction using a magnetic levitation tribometer (MLT), with $n$-alkane $\left(\mathrm{C}_{n} \mathrm{H}_{2 n+2}\right)$, monolayer films adsorbed onto atomically flat surface of gold as lubricant. The structure of the monolayers is controlled using a scanning tunneling microscope (STM) with molecular resolution before and after tribological studies to avoid the destructive modes of MLT measurements.

The $n$-alkane $\left(\mathrm{C}_{n} \mathrm{H}_{2 n+2}, n=14,16,48,50,60\right)$ monolayer films are applied by deposition from solutions warmed up to $\sim 40{ }^{\circ} \mathrm{C}$, with $n$-tetradecane $\left(\mathrm{C}_{14} \mathrm{H}_{30}, \mathrm{C}_{14}\right)$. as solvent. The concentrations of the solutions are selected experimentally so that to obtain a monolayer after complete deposition of the studied molecules on the atomically flat surface of gold. The monolayer structure is studied by the STM method at a liquid/solid interface using a laboratory-modified commercial STM (NT-MDT, Russia).

\section{MAGNETIC LEVITATION TRIBOMETER}

A block diagram of an experimental device for measuring the coefficients of friction between two solid materials is shown in Fig. 1. The method of friction study has been described in detail in [15]. The levitation tribometer consists of the two main elements: a pivot-shaped pendulum with two magnets on it and a magnetic cushion beneath it. The magnets enable hanging pendulum with a metal ball at the end. The test sample is fixed on a vertical holder in front of the ball. During the measurements, the pendulum is pulled out of equilibrium position and oscillates around its axis with damping amplitude. The angular deviation of the pendulum is recorded as function of time $\varphi(t)$. The friction coefficient $\mu_{\mathrm{ko}}$ is determined based on the pendulum oscillations damping curve.

The ball hold-down force is controlled by the angle of inclination of the pendulum bearing surface $\alpha$ to the horizon. The condition of the interface surface before and after MLT measurements is checked by the optical and STM microscopy methods.

\section{SELF-ASSEMBLING OF $n$-ALKANE MOLECULES ON ATOMICALLY FLAT SURFACE OF GOLD}

The STM studies of self-assembled monolayer films of $n$-alkane $\left(\mathrm{C}_{n} \mathrm{H}_{2 n+2}\right)$ homologous series have been described in $[8,9,16,17]$. The molecules are established to form a lamellar structure.

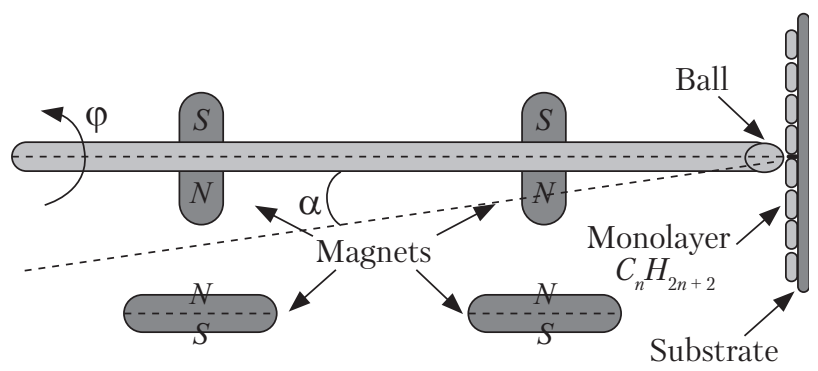

Fig. 1. Block diagram of magnetic levitation tribometer 
Fig. 2 shows a STM image of a pentacontane $\left(\mathrm{C}_{50} \mathrm{H}_{102}\right)$, monolayer adsorbed on atomically flat surface of gold.

The distance between the major axes of neighboring molecules in the adsorbed monolayer (Fig. 2) is $\sim 5 \AA$ [18], and the monolayer is stretched by a substrate in the direction $<112>$. Despite the mutual attraction, the molecules are keeping their adsorption positions, that means the adhesive interaction (molecule/substrate) prevails over the lateral (molecule/molecule) one. Preliminarily, the n-alkanes have been established to be always adsorbed into every second groove. This allows us to consider the gold surface as a system of parallel grooves with a period of $\sqrt{3 \mathrm{~T}}_{\mathrm{Au}}=5 \AA$.

\section{MODEL OF PROPORTIONALITY OF THE PERIODS OF THE ALKANE MOLECULE AND THE GOLD SURFACE ATOMS}

In $[9,17]$, it has been shown that the interaction of $n$-alkane molecules with gold surface depends on their length. The calculations of the slip force $F_{s}$ amplitudes have shown that for the magical lengths of $n$-alkanes ( $n$ times 16 ), the value of $F_{s}$ is abnormally low. Thus, the molecules of ma-

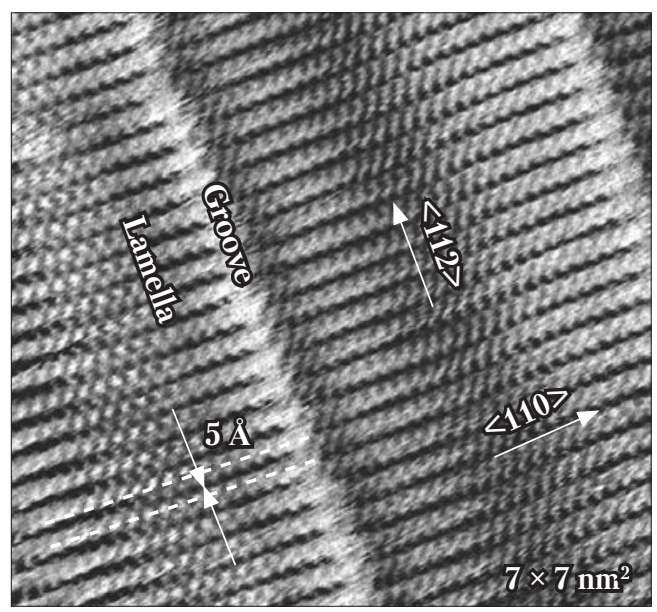

Fig. 2. STM image of a monolayer of pentacontane molecules $\left(\mathrm{C}_{50} \mathrm{H}_{102}\right)$ on atomically flat surface of gold. $<110>$ and $<112>$ show the directions of the gold surface along which the major axes of $\mathrm{C}_{50} \mathrm{H}_{102}$ molecules are located and the lamellae are formed gical length slide along the adsorption grooves almost barrier-free. This theoretical assumption has been confirmed experimentally using MLT measurements. The friction coefficient $\mu_{\mathrm{ko}}$ has been found to non-monotonically depend on the alkane length (the number of $\mathrm{CH}_{2}$ groups in the chain of the molecule).

The basic principles of the proposed one-dimensional model of proportionality of the periods of the alkyl chain and the gold surface atoms along the direction $<110>$ are described below. Fig. 3 schematically shows a zigzag skeleton of an alkyl chain consisting of the carbon atoms $i$ and the gold surface represented by the atoms $j$. The main axis of the molecule runs parallel to the crystallographic direction $<110>$ of the gold surface.

The model is based on the following assumptions: the n-alkane molecule is a rigid skeleton of carbon atoms (Fig. 3); gold substrate is assumed a periodic arrangement of atoms along the direction $\langle 110>$; the interaction between the molecule and the substrate is described by the LennardJones potential while the molecule is moving along the adsorption groove (direction $<110>$ ); the influence of hydrogen atoms in the alkyl chain is neglected.

The slip force $F_{s}(x)$ is calculated from the Lennard-Jones potential as sum of the forces $f_{<110>i j}$ [17]. In this case, $f_{<110>i j}$ describes the interaction between the i-atom of the $n$-alkane molecule and the $j$-atom of the gold surface in the direction $<110>$ (Fig. 3).

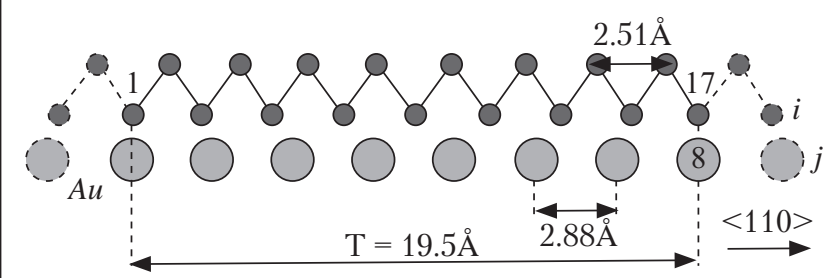

Fig. 3. Schematic representation of alkyl chain $\left(-\mathrm{CH}_{2}-\right)_{n}$, adsorbed on the surface of the gold substrate (111). The periodicity of the alkyl chain and the gold atoms along the direction $<110>$ is $T=19,5 \AA$, which corresponds to 17 carbon atoms and 8 gold atoms. The scale of the drawing along the direction $<110>$ is met 
The location of the $1^{\text {st }}$ and $8^{\text {th }}$ gold $(\mathrm{Au})$ atoms coincides with the 1 st and $17^{\text {th }}-\mathrm{CH}_{2}$ groups of the alkyl chain with an error of $\sim 2 \%$. Thus, 7 periods of the gold atoms correspond to 8 periods of the alkyl chain. The proportionality period $T_{c}$ for such a system [9] can be calculated as

$$
T_{c}=\frac{T_{a l} \cdot T_{A u}}{\left|T_{a l}-T_{A u}\right|},
$$

where $T_{a l}$ is the period of alkyl chain, $T_{A u}$ is the period of gold crystal lattice.

Provided $T_{a l}=2.51 \AA, T_{A u}=2.88 \AA, \mathrm{T}_{c}$ is equal to $19.5 \AA$. The obtained value is an intermediate value between the length of $n$-hexadecane (C16) and $n$-heptadecane (C17) ( 19.05 and $\sim 20.3 \AA$, respectively) [9].

\section{TRIBOLOGICAL PROPERTIES OF THE STEEL BALL//N-ALKANE/GOLD SYSTEM}

The results of measuring the friction coefficients of the steel ball / n-alkane / gold surface tribo-couple are illustrated in Fig. 4. The normal ball load on the monolayer film is $0.049 \mathrm{~N}$. The radius of the ball-gold surface contact $r_{0}$ is obtained by the optical method $\left(r_{0}=1.0 \times 10^{-5} \mathrm{M}\right)$. This value of $r_{0}$ has been used while calculating the friction coefficients.

To take into account possible damages that the steel ball can cause to the gold surface, the friction coefficients of the steel ball $/ \mathrm{mica}\left(\mu_{\mathrm{ko}}=0.17\right)$ and a steel ball/gold $\left(\mu_{\mathrm{ko}}=0.34\right)$. tribological couples were measured. The surface of the studied sample was additionally inspected for defects using an optical microscope and a STM before and after MLT experiments. The results showed no damage to the sample surface.

The kinetic friction coefficient $\mu_{\mathrm{ko}}$ shall depend linearly on the length of the n-alkane molecule. However, as the results of the experiments have shown, this relationship is not linear. For the lengths of $n$-alkanes divisible by $n=16$ carbon atoms, the friction coefficient is much lower than it is expected. Thus, for C16 and C48 molecules, $\mu_{\mathrm{ko}}$ is equal to 0.17 , whereas for the nearest neighbors C14 and C50, it amounts to 0.2 and 0.22, res-

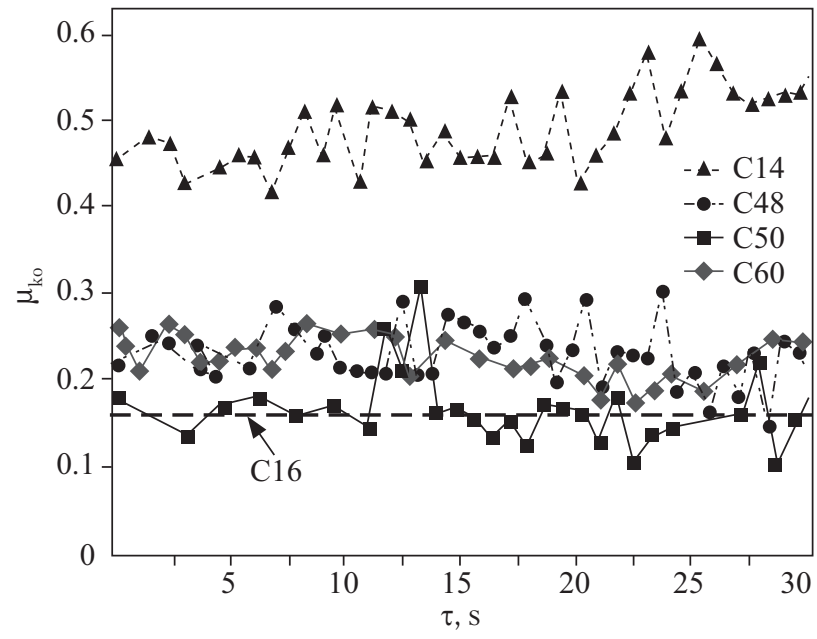

Fig. 4. Changes in the friction coefficients $\mu_{\mathrm{ko}}(\tau)$ for the steel ball/n-alkane/gold surface tribological pair

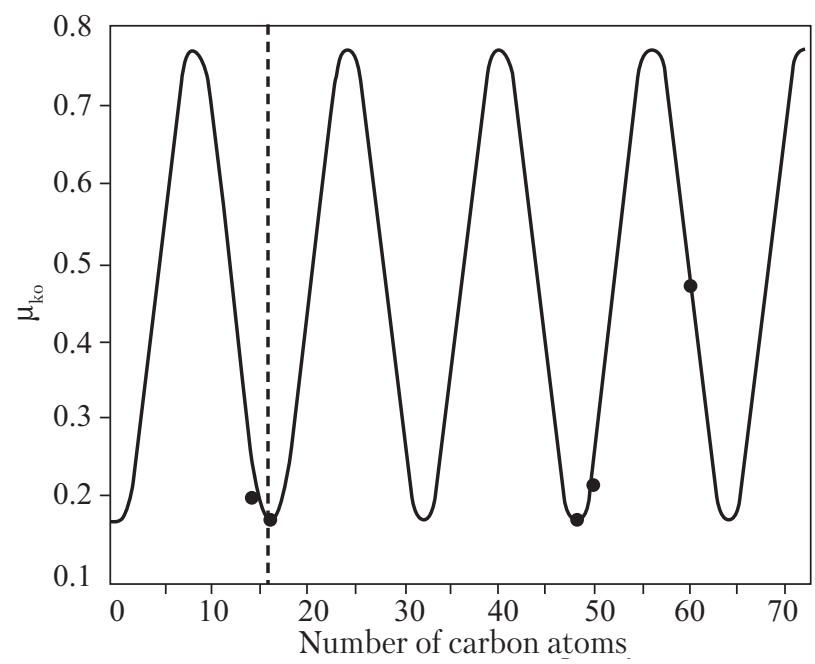

Fig. 5. Dependence of the friction coefficient $\mu_{\mathrm{ko}}$ on the length of the $n$-alkane molecule: experimental data (dots) and their extrapolation (curve) by the function $\mu_{\mathrm{ko}}(\mathrm{n})=$ $-0.3 \times \cos (0.3927 \times n)+0.47$

pectively. Fig. 5 shows the nonmonotonic dependence of $\mu_{\mathrm{ko}}$ on the number $n$ of carbon atoms in the chain of the $n$-alkane molecule. The empirical dependence of the friction coefficient $\mu_{\mathrm{ko}}$ can be written as

$$
\mu_{\mathrm{ko}}\left(\frac{2 \pi}{T} L\right) \sim-\cos \left(\frac{2 \pi}{T} L\right),
$$

where $\frac{2 \pi}{T}$ is frequency of varying friction coef- 
ficient, $L$ is length of $n$-alkane molecule. The obtained result correlates with the model of proportionality of the periods of the alkane molecules $T_{a l}$ and the gold substrate atoms $T_{A u}$ given in $[9,10,16]$.

Thus, with the help of magnetic levitation tribometer, the tribological properties of the $n$-alkane $(n=14,16,48,50,60) /$ gold surface interface have been studied. The alkanes with the "magical length" ( $n$ times 16) have been experimentally confirmed to have abnormally reduced coefficient $\mu_{\mathrm{ko}}$ The obtained result is in good agreement with the theoretical assumption obtained from the model of proportionality of the periods between the alkyl chain $(2.51 \AA)$ and the interatomic distance of gold $(2.88 \AA)$ in the direction $<110>$.

The research has been carried out within the framework of project No. P15 /18-26 Development of a System for Measuring the Tribological Characteristics of Ultra-Thin Films.

\section{REFERENCES}

1. Polyakov, B., Vlassov, S., Dorogin, L. M., Novoselska, N., Butikova, J., Antsov, M., Oras, S., Lohmus, R., Kink, I. (2014). Some aspects of formation and tribological properties of silver nanodumbbells. Nanoscale Research Letters, 9, 186, 1-8. https://doi.org/10.1186/1556-276X-9-186

2. Polyakov, B., Vlassov, S., Dorogin, L., Butikova, J., Smits, K., Antsov, M., Oras, S., Zabels, R., Lohmus, R. (2015). Metal nanodumbbells for nanomanipulations and tribological experiments. Physica Scripta, 90(9), 094007(1-7). https:// doi.org/10.1088/0031-8949/90/9/094007

3. Denape, J. (2015). Third body concept and wear particle behavior in dry friction sliding conditions. Key Engineering Materials, 640, 1-12. https://doi.org/10.4028/www.scientific.net/KEM.640.1

4. Persson, B. N. J. (1998). Sliding Friction: Physical Principles and Applications. Berlin, Springer-Verlag, 1998.

5. Persson, B. N. J. (1999). Sliding friction. Surf. Sci. Rep., 33(3), 83-119. https://doi.org/10.1016/S0167-5729(98) 00009-0

6. Persson, B. N. J. (1995). Theory of friction: Stress domains, relaxation, and creep. Phys. Rev., B 51(19), 13568-13585. https://doi.org/10.1103/PhysRevB.51.13568

7. Vakis, A. I., Yastrebov, V. A., Scheibert, J., Nicola, L., Dini, D., Minfray, C., Almqvist, A., Paggi, M., Lee, S., Limbert, G., Molinari, J. F., Anciaux, G., Echeverri Restrepo, S., Papangelo, A., Cammarata, A., Nicolini, P., Aghababaei, R., Putignano, C., Stupkiewicz, S., Lengiewicz, J., Costagliola, G., Bosia, F., Guarino, R., Pugno, N. M., Carbone, G., M ser, M. H., Ciavarella, M. (2018). Modeling and Simulation in Tribology Across Scales: an Overview. Trib. Int., 125, 169-199. https://doi.org/10.1016/ j.triboint.2018.02.005

8. Askadskaya, L., Rabe, J. P. (1992). Anisotropic molecular dynamics in the vicinity of order-disorder transitions in organic monolayers. Phys. Rev. Lett., 69(9), 1395-2002.

9. Marchenko, O., Cousty, J. (2000). Molecule length-induced reentrant self-organization of alkanes in monolayers adsorbed on Au(111). Phys. Rev. Lett., 84(23), 5363-5366. https://doi.org/10.1103/PhysRevLett.69.1395

10. Marchenko, A., Cousty, J., Pham-Van, L. (2002). Magic Length Effects in the Packing of n-Alkanes Adsorbed on $\mathrm{Au}(111)$. Langmuir, 18, 1171-1175. https://doi.org/10.1021/la010827m

11. Vasko, A. A., Kutsenko, V. Ye., Marchenko, A. A., Braun, O. M. (2019). Lowering of friction in monolayers of mixed alkanes. Tribol. Lett., 67(49), 1-7. https://doi.org/10.1007/s11249-019-1163-x

12. Binnig, G., Quate, C. F., Gerber, C. (1986). Atomic force microscope. Phys. Rev. Lett., 56(9), 930-934. https://doi. org/10.1103/PhysRevLett.56.930

13. Mate, C. M., McClelland, G. M., Erlandsson, R., Chang, S. (1987). Atomic-scale friction of a tungsten tip on a graphite surface. Phys. Rev. Lett., 59(17), 1942-1945. https://doi.org/10.1103/PhysRevLett.59.1942

14. Bhushan B. Handbook of Micro / Nanotribology. CRC, Boca Raton, Florida. 1998. 880pp.

15. Vasko, A. A., Braun, O. M., Marchenko, O. A., Naumovets, A. G. (2018). Magnetic levitation tribometer: a pointcontact friction. Tribol. Lett., 66(74), 1-5. https://doi.org/10.1007/s11249-018-1024-Z

16. MCGonigal, G.C., Bernhard, R.H., Thomson, D.J. (1990). Imaging alkane layers at the liquid/graphite interface with the scanning tunneling microscope. Appl. Phys. Lett., 57(1), 28-30. https://doi.org/10.1063/1.104234

17. Marchenko, A., Lukyanets, S., Cousty, J. (2002). Adsorption of alkanes on Au(111): Possible origin of STM contrast at the liquid/solid interface. Phys. Rev., B 65(4), 04514(1-5). https://doi.org/10.1103/PhysRevB.65.045414 
18. Denicolo, I., Doucet, J., Craievich, A. F. (1983). X-ray study of the rotator phase of paraffins (III): Even-numbered paraffins $\mathrm{C}_{18} \mathrm{H}_{38}, \mathrm{C}_{20} \mathrm{H}_{42}, \mathrm{C}_{22} \mathrm{H}_{46}, \mathrm{C}_{24} \mathrm{H}_{50}$, and $\mathrm{C}_{26} \mathrm{H}_{54}$. J. Chem. Phys., 78(3), 1465-1469. https://doi.org/10.1063/1.444835

Received 04.12.18

Revised 28.02.19

Accepted 01.03.19

\author{
А.А. Васько, А.А. Марченко, А.Г. Наумовець, О.М. Браун \\ Інститут фізики НАН України, \\ просп. Науки, 46, Київ, 03680, Украина, \\ +380445251220, +380445251589 \\ artem.vasko@ukr.net

\section{ДОСЛІДЖЕННЯ ТРИБОЛОГІЧНИХ ВЛАСТИВОСТЕЙ МОНОШАРОВИХ ПЛІВОК N-АЛКАНІВ НА АТОМНО-ГЛАДКІЙ ПОВЕРХНІ ЗОЛОТА}

Вступ. Встановлення закономірностей взаємодії мікроконтактів в інтерфейсі тертя, утвореного двома рухомими тілами, є важливим кроком для створення нових класів матеріалів з визначеними фізико-хімічними властивостями. При відносному русі взаємодіючих поверхонь неминуче відбувається зношування їх контактуючих ділянок (мікроконтактів), в результаті чого в інтерфесі тертя виникають уламки, спричинені руйнуванням більш еластичного матеріалу.

Проблематика. Ступінь руйнування інтерфейсу суттєво зменшується при додаванні мастильних плівок в місці контакту. Якщо за умов сухого тертя (без мастила) аналіз місця контакту є практично вирішеною задачею (модель контактної взаємодії Герца, Джонсона-Кендала-Робертса), то при наявності мастила ця задача істотно ускладнюється через необхідність врахування фактору реологічної складової тертя та фактору інтерфейсної взаємодії. Окрім того, переважну більшість трибологічних досліджень виконано на недосконалих (шорстких) поверхнях з використанням мастильних плівок з невизначеними компонентним складом, товщиною і структурою.

Мета. Встановлення впливу структури самовпорядкування моношарових плівок на їх трибологічні властивості в інтерфейсі тертя $n$-алкан/атомно-гладка поверхня.

Матеріали й методи. Використано атомно-гладкі поверхнї золота та однокомпонентні змащувальні моношарові плівки $n$-алканів $\left(\mathrm{CnH}_{2 n+2}, n=14,16,48,50,60\right)$. Для встановлення структури самовпорядкування плівок на поверхні золота і контролю ступеню їх руйнування до і після трибологічних вимірювань застосовано сканувальну тунельну мікроскопію. Кінетичний коефіцієнт тертя $\mu_{\mathrm{ko}}$ інтерфейсів виміряно за допомогою магнітного левітаційного трибометра.

Результати. Експериментально встановлено немонотонну залежність коефіцієнта тертя $\mu_{\mathrm{ko}}$ від довжини молекул змащувальних плівок.

Висновки. Встановлено, що для $n$-алканів 3 «магічною довжиною» ( $n$ кратне 16$) \mu_{\text {ко }}$ аномально зменшується

Ключові слова: коефіцієнт тертя, атомно-гладкі поверхні, моношарові плівки $n$-алканів, сила тертя.

\author{
А.А. Васько, А.А. Марченко, А.Г. Наумовеи, О.М. Браун \\ Институт физики НАН Украины, \\ просп. Науки, 46, Киев, 03680, Украина, \\ +380445251220, +380445251589 \\ artem.vasko@ukr.net
ИССЛЕДОВАНИЕ ТРИБОЛОГИЧЕСКИХ СВОЙСТВ МОНОСЛОЙНЫХ ПЛЕНОК N-АЛКАНОВ НА АТОМНО-ГЛАДКОЙ ПОВЕРХНОСТИ ЗОЛОТА

Введение. Установление закономерностей взаимодействия микроконтактов в интерфейсе трения, образованного двумя подвижными телами, является важным шагом для создания новых классов материалов с определенными физико-химическими свойствами. При относительном движении взаимодействующих поверхностей неизбежно происходит износ их контактирующих участков (микроконтактов), в результате чего в интерфейсе трения возникают обломки, вызванные разрушением более эластичного материала.

Проблематика. Степень разрушения интерфейса существенно уменьшается при добавлении смазочных пленок в область контакта. Если в условиях сухого трения (без смазки) описание места контакта является практически ре- 
шенным заданием (модель контактного взаимодействия Герца, Джонсона-Кендалла-Робертса), то при наличии смазки эта задача существенно усложняется из-за необходимости определения фактора реологической компоненты трения и фактора интерфейсного взаимодействия. Кроме того, подавляющее большинство трибологических исследований выполнено на несовершенных (шероховатых) поверхностях с использованием смазочных пленок с неопределенными компонентным составом, толщиной и структурой.

Цель. Установление влияния структуры самоупорядочения монослойных пленок на их трибологических свойства в интерфейсе трения $n$-алкан/атомно-гладкая поверхность.

Материалы и методы. Использованы атомно-гладкие поверхности золота и однокомпонентные смазочные монослойные пленки $n$-алканов $\left(\mathrm{C}_{n} \mathrm{H}_{2 n+2}, n=14,16,48,50,60\right)$. Для установления структуры самоупорядочения пленок на поверхности золота и контроля степени их разрушения до и после трибологических измерений использовано сканирующую туннельную микроскопию. Кинетический коэффициент трения $\mu_{\mathrm{ko}}$ интерфейсов измерено с помощью магнитного левитационного трибометр.

Результаты. Экспериментально установлено немонотонную зависимость коэффициента трения $\mu_{\mathrm{ko}}$ от длины молекул смазочных пленок.

Выводы. Установлено, что для $n$-алканов с «магической длиной» ( $n$ кратно 16) $\mu_{\text {ко }}$ аномально уменьшается.

Ключевые слова: коэффициент трения, атомно-гладкие поверхности, монослойные пленки $n$-алканов, сила трения. 